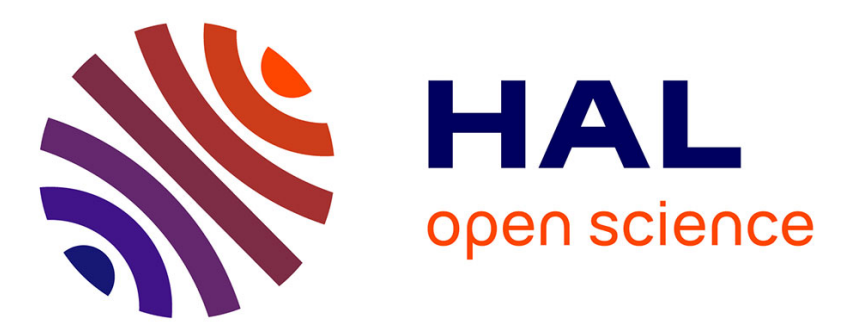

\title{
A One-Pot Regiospecific Synthesis of Highly Functionalized 1,4-Benzodioxin Derivatives from an Electrochemically Induced Diels-Alder Reaction
}

Daiwang Xu, Angèle Chiaroni, Martine Largeron

\section{- To cite this version:}

Daiwang Xu, Angèle Chiaroni, Martine Largeron. A One-Pot Regiospecific Synthesis of Highly Functionalized 1,4-Benzodioxin Derivatives from an Electrochemically Induced Diels-Alder Reaction. Organic Letters, 2005, 7 (23), pp.5273-5276. 10.1021/ol052146e . hal-02384997

\section{HAL Id: hal-02384997 \\ https://hal.science/hal-02384997}

Submitted on 27 Nov 2020

HAL is a multi-disciplinary open access archive for the deposit and dissemination of scientific research documents, whether they are published or not. The documents may come from teaching and research institutions in France or abroad, or from public or private research centers.
L'archive ouverte pluridisciplinaire HAL, est destinée au dépôt et à la diffusion de documents scientifiques de niveau recherche, publiés ou non, émanant des établissements d'enseignement et de recherche français ou étrangers, des laboratoires publics ou privés. 


\title{
A One-pot Regiospecific Synthesis of Highly Functionalized 1,4-Benzodioxin Derivatives from an Electrochemically Induced Diels- Alder Reaction
}

\author{
Daiwang $\mathrm{Xu}^{\#}$, Angèle Chiaroni ${ }^{\S}$, and Martine Largeron ${ }^{\star}, \#$ \\ UMR 8638 Synthèse et Structure de Molécules d'Intérêt Pharmacologique, CNRS- \\ Université Paris 5, 4 avenue de l'observatoire, 75270 Paris cedex 06, France and \\ Institut de Chimie des Substances Naturelles, Centre National de la Recherche \\ Scientifique, 91198 Gif-sur-Yvette cedex, France
}

martine.largeron@univ-paris5.fr

Received Date (will be automatically inserted after manuscript is accepted)

ABSTRACT

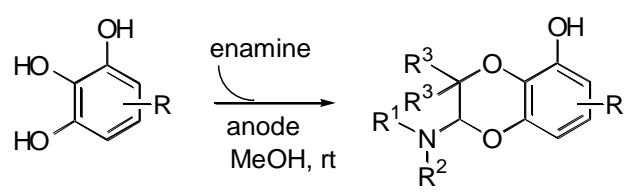

The anodic oxidation of pyrogallol derivatives produces chemically unstable o-quinone heterodienes, which are trapped in situ by enamine dienophiles through regiospecific inverse-electron-demand Diels-Alder reactions. The possibility of introducing variations in both cycloaddition partners gives rise to highly substituted 1,4-benzodioxin cycloadducts with up to five elements of diversity. The reactions proceed under mild conditions with a good efficiency. The methodology should be amenable to the assembly of libraries of biologically relevant heterocycles.

Various 1,4-benzodioxin derivatives have been shown to display very interesting pharmacological properties including anti-inflammatory, diuretic, anti-hyperglycemic, and calcium antagonistic activities. ${ }^{1}$ Some of them are also antagonists of $\alpha$-adrenergic receptors at the origin of anti-hypertensive properties, while others have affinities with serotonin receptors which are involved in nervous breakdown and schizophrenia. ${ }^{2}$

\footnotetext{
\# UMR 8638 CNRS-Université Paris 5

$\S$ Institut de Chimie des Substances Naturelles, CNRS, Gif-surYvette

(1) Guillaumet, G. in Comprehensive Heterocyclic Chemistry II, 1 st ed ; Katritzky, A.R., Rees, C. W., Scriven, E.F.V., Eds.; Pergamon: Oxford, 1996; Vol . 6, p 447.
}

Among the different methods leading to the 1,4benzodioxin scaffold, the Diels-Alder reaction may provide access to a wide molecular diversity through the variation of the structure of both cycloaddition partners.

(2) For some examples see (a) Comoy, C.; Benarab, A.; Monteil, A.; Leinot, M.; Massingham, R.; Guillaumet, G. Med. Chem. Res. 1996, 392-399. (b) Birch, A.M.; Bradley, P.A.; Gill, J.C.; Kerrigan, F.; Needham, P.L. J. Med. Chem. 1999, 42, 3342-3355. (c) Bolognesi, M.L.; Budriesi, R.; Cavalli, A.; Chiarini, A.; Gotti, R.; Leonardi, A.; Minarini, A.; Poggesi, E.; Recanatini, M; Rosini, M.; Tumiatti, V.; Melchiorre C. J. Med. Chem. 1999, 42, 4214-4224 and references therein. (d) Depoortere, R.; Boulay, D.; Perrault, G.; Bergis, O.; Decobert, M.; Françon, D.; Jung, M.; Simiand, J.; Soubrié, P.; Scatton, B. Neuropsychopharmacology 2003, 28, 1889-1902. (e) Gilbert, A.M.; Stack, G.P.; Nilakantan, R.; Kodah, J.; Tran, M.; Scerni, R.; Shi, X.; Smith, D.L.; Andree, T.H. Bioorg. Med. Chem. Lett. 2004, 14, 515-518. 
Despite this potential, the synthetic scope of this reaction is limited by the requirement of $o$-quinone heterodienes which are not readily accessible stable compounds. Most of the work has been generally restricted to specific $o$ quinone heterodienes, mainly to 4-tert-butyl $o$-quinone, Corey's reagent, $o$-chloranil, $o$-bromanil, and $o$-naphthoquinones. ${ }^{3}$ To the best of our knowledge, only a few reports described the synthesis of 1,4-benzodioxin derivatives from in situ chemically generated unstable $o$ quinone, and the yield was somewhat low. ${ }^{3 j-1,4}$

Electrochemically induced cycloadditions have proved to be a promising tool for organic chemistry. ${ }^{5}$ Various unstable electrogenerated dienes ${ }^{5 \mathrm{e}-\mathrm{g}}$ or dienophiles ${ }^{5 \mathrm{~h}}$ have been successfully used in Diels-Alder reactions to afford the desired cycloadduct in high yield, with a good stereocontrol.

Recently, we described a cascade reaction traversing through an inverse-electron-demand Diels-Alder (IEDDA) reaction of an $o$-iminoquinone diene and a secondary alkylenamine dienophile, two chemically nonaccessible unstable entities. ${ }^{6}$ Our electrochemical procedure, wherein both cycloaddition partners were generated in situ, at room temperature, under metal-free conditions, allowed the rapid construction of diverse 2alkylamino-1,4-benzoxazine derivatives which proved to be potent neuroprotective agents in vitro and in vivo. ${ }^{6 \mathrm{~d}}$

We report now the electrochemically induced $o$ quinone cycloaddition reaction with enamines, which gives rise to highly functionalized 1,4-benzodioxin derivatives, with complete regiochemical control. This reaction which offers the opportunity to introduce diversity elements in both cycloaddition partners should allow the easy synthesis of libraries of biologically relevant heterocycles.

(3) see for example: (a) Horspool , W.M.; Tedder, J.M.; Din, Z.U. J. Chem. Soc. (C) 1969, 1692-1693. (b) Ansell, M.F.; Bignold, A. J. Chem. Commun. 1969, 1096-1097. (c) Ansell, M.F.; Leslie, V.J. J. Chem. Soc. (C) 1971, 1423-1426. (d) Friedrichsen, W.; Schröer, W.D.; Schmidt, R. Liebigs Ann. Chem. 1976, 793-819, and references therein. (e) Dondoni, A.; Fogagnolo, M. ; Mastellari, A. ; Pedrini, P. ; Ugozzoli, F. Tetrahedron Lett. 1986, 27, 3915-3918. (f) Boger, D.L.; Weinreb, S.N. in Hetero Diels-Alder Methodology in Organic Synthesis, Acaademic Press, Inc. 1987, pp 167-213. (g) Takada, M.; Oshima, R.; Yamauchi, Y.; Kumanotani, J.; Seno, M. J. Org. Chem. 1988, 53, 3073-3080. (h) Nair, V.; Kumar, S. J. Chem. Soc Perkin Trans 1 1996, 443-447. (i) Nair, V. ; Kumar, S. Tetrahedron 1996, 52 , 4029-4040. (j) Nair, V.; Kumar, S. Synlett, 1996, 1143-1147 and references therein. (k) Nair, V.; Kumar, S. Synthetic Commun. 1996, 26, 217-224. (1) Nair, V.; Mathew, B.; Radhakrishnan, K.V.; Rath, N.P. Tetrahedron 1999, 55, 11017-11026. (m) Cameron, D.W.; Heisey, R.M. Aust. J. Chem. 2000, 53, 109-121.

(4) (a) Omote, Y.; Tomotake, A.; Kashima, C. Tetrahedron Lett. 1984, 25, 2993-2994. (b) Omote, Y.; Tomotake, A.; Kashima, C. J. heterocyclic. Chem 1984, 21, 1841-1844. (c) Omote, Y.; Tomotake, A.; Kashima, C. J. Chem. Soc. Perkin Trans 1 1988, 151-156. (d) Nair, V.; Kumar, S. Indian J. Chem. 1996, 35B, 5-7.

(5) for some examples see: (a) Yoshida, J.I.; Sakaguchi, K.; Isoe, S. J. Org. Chem. 1988, 53, 2525-2533. (b) Inokuchi, T.; Tanigawa, S.I.; Torii, S. J. Org. Chem. 1990, 55, 3958-3961. (c) Gûrther, C.F.; Blechert, S.; Steckhan, E. Angew. Chem. Int. Ed. 1995, 34, 1900-1901. (d) Peglow, T.; Blechert, S.; Steckhan, E. Chem. Eur. J. 1998, 4, 107112. (e) Jinno, M.; Kitano, Y.; Tada, M.; Chiba, K. Org. Lett. 1999, 1, 435-437 and references therein. (f) Utley, J.H.P.; Ramesh, S.; Salvatella, X.; Szunerits, S.; Motevalli, M.; Nielsen, M.F. J. Chem. Soc. Perkin Trans 2 2001, 153-163. (g) Kise, N.; Mimura, R.; Ueda, N.
Bull. Chem. Soc. Jpn 2002, 75, 2693-2694. (h) Lorans, J.; Hurvois, J.P. ; Moinet, C. Acta Chem. Scand. 1999, 53, 807-813.

Table 1. Variation of the diene part: anodic oxidation of various pyrogallol derivatives 1a-i and trapping of the electrogenerated $o$-quinone heterodiene by 4-cyclohexylidenemethylmorpholine. ${ }^{a}$<smiles></smiles>

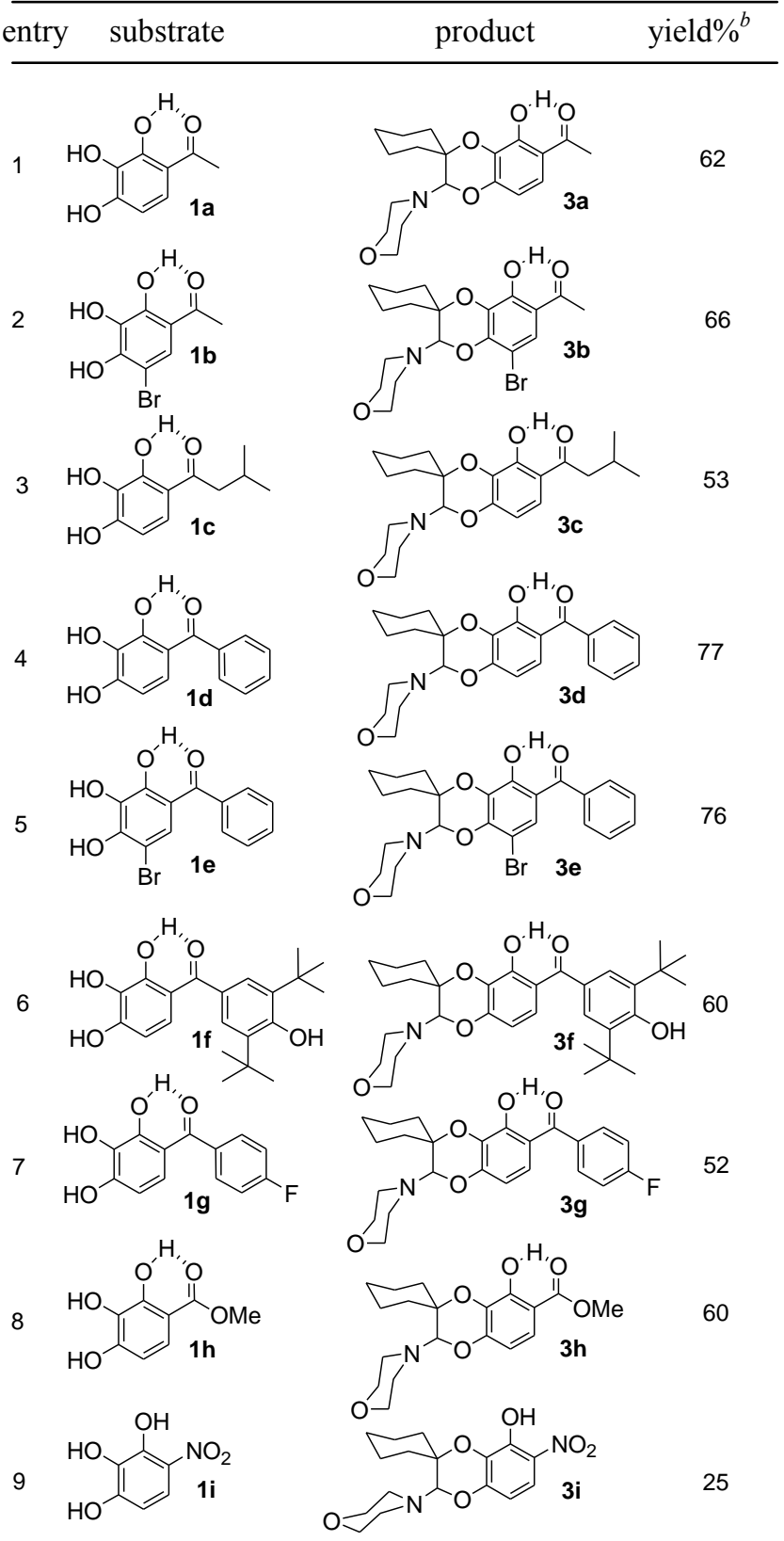

${ }^{a}$ Reagents and conditions: $(\mathbf{1 a}-\mathbf{i})=2 \mathrm{mM}$ (added in four equal portions $),($ enamine $)=10 \mathrm{mM}, \mathrm{MeOH}, \mathrm{rt}, \mathrm{Hg}$ anode $(\mathrm{E}=+50 \mathrm{mV}$ vs SCE), $4 \mathrm{~h}$; 1 equiv of morpholine was added to the bulk solution for producing the monoanionic species of $\mathbf{1 a - i}$, which is the sole form that can be oxidized to $o$-quinone. ${ }^{b}$ Yields refer to chromatographically pure isolated products. 
We first performed optimization studies of the anodic controlled-potential electrolysis of pyrogallol derivatives, using 1a in the presence of 4cyclohexylidenemethylmorpholine 2a. We found that the optimum conditions required a mercury anode, methanol as the solvent and tetraethylammonium hexafluorophosphate as the supporting electrolyte. One equivalent of $1 \mathrm{a}$ and 5 equiv of enamine were a good reagent combination for the reaction. However, due to the instability of the electrogenerated 3,4-quinone heterodiene, compound 1a was added in four equal portions to the electrolysis solution which contained the enamine dienophile. In the meantime, the anode potential was maintained at $+50 \mathrm{mV}$ vs $\mathrm{SCE}$, which is at a potential for which 1a could be oxidized to the corresponding 3,4-quinone form. Thus, the continuously low concentration of the electrogenerated o-quinone heterodiene, together with the large excess of enamine dienophile, should promote the cycloaddition reaction at the expense of the polymerization of the putative 3,4quinone. Under these reaction conditions, compound 3a was isolated in $62 \%$ yield as a single regioisomer (entry 1 , Table 1). ${ }^{7}$

With the reliable set of conditions in hand, we probed the scope of the electrochemically induced cycloaddition reaction with different $o$-quinone heterodienes. Table 1 shows some examples of the molecular diversity that is accessible through this reaction which is an IEDDA reaction between the electron-poor $o$-quinone heterodiene and the electron-rich enamine dienophile. This uncatalyzed cycloaddition reaction occurred at room temperature, within $4 \mathrm{~h}$, with complete regioselectivity. The more electron-rich carbon atom of the enamine dienophile added to the 3-oxygen atom of the $o$-quinone heterodiene. Conclusive evidence of the structure of the regioisomer was provided by X-ray crystallographic analyses of the benzodioxin derivative $\mathbf{3 h}$ (Figure 1). Interestingly, bromosubstituted pyrogallol derivatives reacted effectively to furnish the desired cycloadduct in good yields (entries 2 and 5, Table 1). ${ }^{8}$ In the specific case of pyrogallol derivatives bearing a benzophenone framework (entries 4-7), the scope of the cycloaddition reaction could be also extended by the attachment of substituents on the benzoyl moiety. As we suspected that electron-poor $o$-quinone heterodienes possessing electron withdrawing groups on the benzoyl moiety should favor the IEDDA reaction with the electron-rich enamine, we focused on introduction of electron-donating substituents.

(6) Largeron, M.; Neudörffer, A.; Vuilhorgne, M.; Blattes, E.; Fleury, M.-B. Angew. Chem. Int. Ed. 2002, 41, 824-827. (b) Blattes, E.; Fleury, M.-B.; Largeron, M. J. Org. Chem. 2004, 69, 882-890. (c) Blattes, E.; Fleury, M.-B.; Largeron, M. Electrochim. Acta 2005, 50, 4902-4910. (d) Blattes, E.; Lockhart, B.; Lestage, P.; Schwendimann, L.; Gressens, P.; Fleury, M.-B.; Largeron, M. J. Med. Chem. 2005, 48, 1282-1286.

(7) Various solvents and reaction conditions were screened, but none of changes led to an improvement of the yield of the reaction. Replacing the $\mathrm{Hg}$ anode by a Pt anode for instance lowered the yield to $50 \%$.

(8) Bromosubstituted aromatic rings are particularly attractive in diversity-oriented synthesis because they can be easily transformed into differently substituted aromatics by cross-coupling reactions.
Table 2. Variation of the dienophile part: anodic oxidation of pyrogallol derivatives $\mathbf{1 d}$ and $\mathbf{1 e}$ and trapping of the corresponding $o$-quinone heterodiene by different enamines. ${ }^{a}$

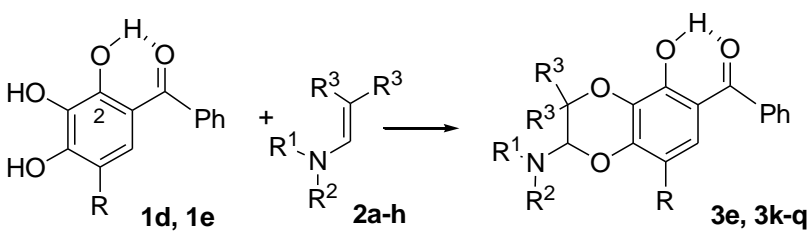

\begin{tabular}{|c|c|c|c|}
\hline entry & enamine & product & yield $\%{ }^{b}$ \\
\hline
\end{tabular}

1

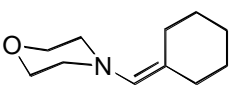

2a<smiles>CC(C)=CN1CCOCC1</smiles>
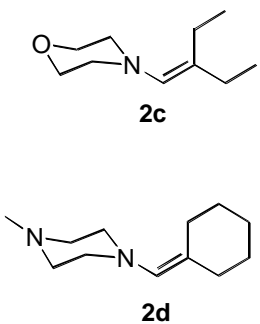

2d<smiles>CC(C)=CN1CCN(C)C1</smiles>

5<smiles>C1CCC(N2CCOC2)CC1</smiles>

6<smiles>[2H]c1c(C(=O)c2ccccc2)cc(Br)c2c1OC(CCC)(CCCC)C(N1CCOCC1)O2</smiles>
76<smiles>CN(CC1CCCCC1)CC1OCCO1</smiles>

2g<smiles>C/C=C(\c1ccccc1)c1ccc2c(c1C)OC(N(C)CC1OCCO1)C1(CC3CCCC1C3)O2</smiles>

$35^{d}$

8<smiles>COCCNC1Oc2ccc(C(=O)c3ccccc3)c([O])c2OC1(c1ccccc1)c1ccccc1</smiles><smiles>CC(Br)=C(OC(C)N1CCN(C)CC1)C(C)O[O-]</smiles><smiles>CC1(C)Oc2c(O)c(C(=O)c3ccccc3)cc(I)c2OC1N1CC1</smiles><smiles>CN(C)CC1CCCC2(N)Oc3ccc(C(=O)c4ccccc4)c([O])c3OC12</smiles>

${ }^{a}$ Reagents and conditions: (1d, 1e) $=2 \mathrm{mM}$ (added in four equal portions $),($ enamine $)=10 \mathrm{mM}, \mathrm{MeOH}, \mathrm{rt}, \mathrm{Hg}$ anode $(\mathrm{E}=+50 \mathrm{mV}$ vs $\mathrm{SCE}), 4 \mathrm{~h}$; 1 equiv of morpholine was added to the bulk solution for producing the monoanionic species of $\mathbf{1 d}$ or $\mathbf{1 e}$, which is the sole form that can be oxidized to $o$-quinone. ${ }^{b}$ Yields refer to chromatographically pure isolated products. ${ }^{c}$ obtained as a mixture of two unassigned diastereoisomers. ${ }^{d} 2$-hemiacetal was isolated as the by-product in $20 \%$ yield. 
Surprisingly, the presence of electron-donating groups did not significantly interfere with the reaction since the yield of the cycloadduct only slightly decreased (entries 6 and 7). Anodic oxidation of 1-nitropyrogallol 1i generated a highly unstable $o$-quinone heterodiene which, as a result of its concomitant decomposition to melanin-like polymers, failed to produce the corresponding cycloadduct $3 \mathbf{i}$ in good yield (entry 9 ).

The regiospecificity of the reaction deserves special note because the regioselectivity of earlier reported similar reactions was quite variable. ${ }^{3,4}$ Furthermore, when the pyrogallol derivative $\mathbf{1 d}$ was replaced by its corresponding 2-methoxy analogue $\mathbf{1 j}$, the electrochemically induced cycloaddition reaction led to a 4:1 mixture of regioisomers $\mathbf{3} \mathbf{j a}$ and $\mathbf{3 j b}$ ( $75 \%$ combined, Scheme 1). ${ }^{9}$ This result highlighted the crucial role of the 2-hydroxyl group as the inducer of regiospecificity. This point merits thorough further investigation.

Scheme 1. Anodic oxidation of the 2-methoxy analogue $\mathbf{1} \mathbf{j}$ and in situ trapping of the $o$-quinone heterodiene by enamine $\mathbf{2 a}$.

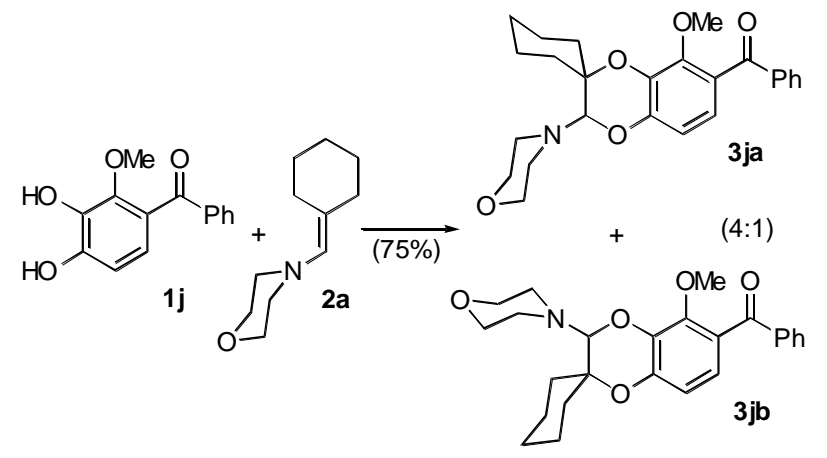

The structure of the enamine dienophile could be also very diverse (Table 2). As expected, alkylenamines with a pronounced electron-rich character produced the desired cycloadduct in high yield (entries 1-6), whereas the enamine $\mathbf{2 h}$ that bore phenyl substituents resulted in somewhat lower yield (entry 8). Except for the cycloadduct 3p (entry 7), no subsequent elimination of the alkylamino chain was observed, in contrast to what has been previously reported for similar reactions of enamines with $o$-quinones. ${ }^{4 c}$ This feature is of synthetic interest since the methodology we describe allows the easy synthesis of 2-alkylamino-1,4-benzodioxin derivatives.

(9) The reaction was performed under the same experimental conditions. However, as $o$-quinol $\mathbf{1} \mathbf{j}$ was oxidizable at a slightly higher potential, the $\mathrm{Hg}$ anode, which has a low anodic decomposition potential, was replaced by a Pt anode.

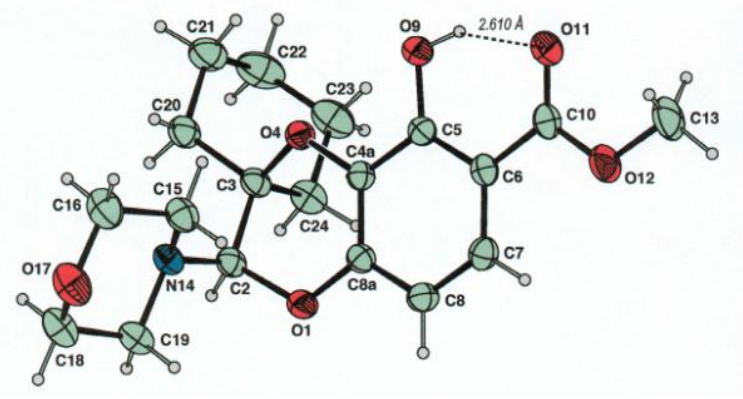

Figure 1. An ORTEP view of $\mathbf{3 h}$. Displacement ellipsoids are drawn at the $30 \%$ probability level. ${ }^{10}$

In conclusion, we have reported a successful use of in situ generated o-quinone heterodienes for the regiospecific IEDDA reaction with enamines. The possibility of introducing variations in both cycloaddition partners afforded highly substituted 1,4-benzodioxin derivatives with up to five elements of diversity. Because it would be difficult to access them more rapidly, our electrochemical methodology proved to be particularly attractive for library development. Finally, as a result of their structural similarity with a series of 1,4-benzoxazine derivatives reported earlier, ${ }^{6 \mathrm{~d}}$ these new compounds could be considered as target structures for the design of novel neuroprotective agents.

Acknowledgments. The authors wish to thank Prof. M.-B. Fleury for fruitful discussions and encouragement. D.X. thanks Paris 5 University and the MRT for a postdoctoral grant.

Supporting Information Available: Typical experimental procedures and full spectroscopic data for compounds 3a-q, including ${ }^{1} \mathrm{H},{ }^{13} \mathrm{C}$ NMR spectra together with crystallographic files (CIF) for compound $\mathbf{3 h}$. This material is available free of charge via the Internet at http://pubs.acs.org.

(10) Crystallographic data for 3h: Prismatic colorless crystal of $0.75 \times 0.40 \times 0.30 \mathrm{~mm}$. Empirical formula $\mathrm{C}_{19} \mathrm{H}_{25} \mathrm{NO}_{6}, M=363.40, T=$ $293 \mathrm{~K}$, Triclinic system, space group $\mathrm{P}-1, \mathrm{Z}=4, a=11.468(3), b=$ 12.662(4), $c=13.310(4) \AA, \alpha=76.23(2), \beta=80.61$ (2), $\gamma=89.87(2)^{\circ}$, $V=1850.7 \AA^{3}, d_{\text {calc }}=1.304 \mathrm{~g} \mathrm{~cm}^{-3}, \mathrm{~F}(000)=776, \mu=0.10 \mathrm{~mm}^{-1}$, $\lambda(\mathrm{MoK} \alpha)=0.71073 \AA$, There are two enantiomeric independent molecules in the asymmetric unit. 13482 reflections measured of which 8462 unique, 478 parameters refined on $F^{2}$. Final $R l(F)=0.0433$ calculated with the 5713 observed reflections as I $>2$ sigma (I), $\mathrm{wR} 2\left(\mathrm{~F}^{2}\right)=0.1156$ (with all the 8462 data) Deposited CCDC number: 282558 